\title{
ANALISIS FAKTOR YANG BERHUBUNGAN DENGAN IMPLEMENTASI PROGRAM SDIDTK OLEH BIDAN DESA DI WILAYAH DINAS \\ KESEHATAN \\ KABUPATEN SEMARANG TAHUN 2014
}

\author{
$\underline{\text { Sri Wahyuni ,Sri Wahyuni, Umaroh }}$
}

\begin{abstract}
ABSTRAK
Masa lima tahun pertama kehidupan merupakan masa yang sangat peka terhadap lingkungan, dan merupakan masa kritis. SDIDTK merupakan salah satu upaya untuk mengatasi masa kritis tersebut. Cakupan SDIDTK di Kabupaten Semarang sebesar 78,5\% hampir mendekati target SPM yaitu $80 \%$. Tujuan dari penelitian ini adalah untuk menganalisa hubungan antara faktor komunikasi, disposisi, sumber daya, dan struktur Birokrasiserta mengetahui pengaruh secara bersama-sama dari variabel tersebut.

Penelitian ini merupakan penelitian kuantitatif korelasional, Metode yang digunakan adalah metode survey dengan pendekatan cross sectional, variabel yang diteliti adalah komunikasi, sumber daya, disposisi, struktur birokrasi, serta implementasi. Analisa data yang digunakana adalah regresi logistik karena variabel dependent tidak berdistribusi normal. Populasi dalam penelitian ini adalah semua bidan desa yang ada diwilayah Dinas Kesehatan Semarang, dengan sampel berjumlah 62 bidan desa yang berasal dari 5 Puskesmas dengan cakupan SDIDTKnya rendah.

Hasil penelitian menunjukkan ada pengaruh secara bersama antara variabel disposisi dan sumber daya, namun variabel yang dominan adalah variabel Disposisi dengan nilai $\mathrm{P}$ value 0,007. Disarankan kepada Puskesmas untuk memantau secara rutin sumber daya baik metoda dan materi dan mengusulkannya kepada Dinas Kesehatan, serta kepada Dinas Kesehatan agar bisa memenuhi usulan tersebut, kepada bidan desa supaya mempunyai komitmen dengan cara meningkatkan pengetahuan dan ketrampilanserta sikap yang baik dalam melaksanakan program SDIDTK.
\end{abstract}

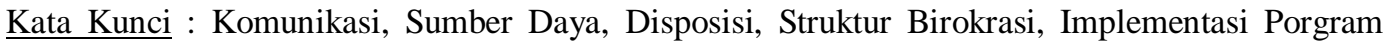
SDIDTK

1,2,3 : Peneliti Dosen Kebidanan Semarang

Pertumbuhan dan perkembangan anak secara fisik, mental, sosial dipengaruhi oleh gizi, kese-hatan dan pendidikan. Penelitian oleh Bloom mengenai kecerdasan menunjukkan bahwa kurun waktu 4 tahun pertama usia anak, perkembangan kognitifnya men- capai sekitar $50 \%$, kurun waktu 8 tahun mencapai $80 \%$ dan mencapai $100 \%$ setelah anak berusai 18 tahun. Masa lima tahun pertama kehi-dupan merupakan masa yang sangat peka terhadap lingkungan disebut masa keemasan (golden period), jendela 
kesempatan (window opportunity) dan masa kritis. Pemerintah telah melakukan berbagai upaya dalam mendukung pelaksanaan SDIDTK (Stimulasi Deteksi Intervensi Dini Tumbuh Kembang) antara lain diterbitkannya buku "Pedoman Pelaksanaan Stimulasi Deteksi dan Intervensi Dini Tumbuh Kembang Anak" pada Tingkat Pelayanan Kesehatan Dasar.

Berdasarkan data dari Dinas Kesehatan Jawa Tengah tahun 2011 cakupan deteksi dini tumbuh kembang anak balita dan prasekolah di Jawa Tengah mencapai 65,88\%, tahun 2012 mengalami peningkatan sebesar $14,33 \%$ dengan cakupan mencapai 80,21\%. Akan tetapi hingga bulan September 2013 cakupan baru mencapai 50,41\% masih dibawah target Depkes yaitu 95\%.

Di Kabupaten Semarang pada tahun 2011 cakupan SDIDTK sebesar 77\%. Tahun 2012 mengalami peningkatan menjadi $78,5 \%$. Walaupun mengalami peningkatan cakupan tersebut masih di bawah target yaitu 90\% (Dinkes, 2012).

Program SDIDTK merupakan salah satu bentuk implementasi kebijakan publik dalam bidang kesehatan yang bertujuan untuk meningkatkan kualitas hidup anak mencapai tumbuh kembang yang optimal. Beberapa upaya yang dilakukan oleh Dinas Kesehatan Kabupaten Semarang dalam mengembangkan pelaksanaan kegiatan SDIDTK di Puskesmas Kabupaten Semarang meliputi 1) Pengadaan Buku kesehatan ibu dan anak dan buku pedoman stimulasi deteksi dan intervensi dini di tingkat pelayanan kesehatan dasar; 2) Pengadaan formulir laporan kesehatan bayi, balita dan anak; 3) Pelatihan SDIDTK bagi tenaga kesehatan di Puskesmas Kabupaten Semarang sebanyak 89 bidan yang terdiri dari 19 bidan koordinator anak dan 70 bidan desa; 4) surat edaran dari kepala Dinas Kesehatan Kabupaten Semarang kepada kepala puskesmas tentang pelaksana kegiatan SDIDTK adalah bidan desa.

Berdasarkan studi pendahu-luan yang dilakukan pada 8 bidan desa di wilayah Kabupaten Semarang didapatkan bahwa: seluruh responden mengatakan bahwa formulir untuk pemeriksaan SDIDTK masih harus dipersiapkan sendiri termasuk alat permainan edukatifnya, Pemeriksaan SDIDTK belum dilakukan pada semua sasaran tapi hanya diambil sampel saja, belum ada koordinasi dengan lembaga pendidikan yang telah melaksanakan SDIDTK.

Berdasarkan data-data diatas maka peneliti tertarik untuk meneliti tentang faktor yang mempengaruhi implementasi program SDIDTK.

\section{Tujuan Penelitian}

Tujuan Umum, Mengetahui faktor - faktor yang berhubungan dengan implementasi program SDIDTK. Tujuan Khusus, Menganalisis hubungan faktor komunikasi dengan implementasi program SDIDTK, Menganalisis hubungan faktor sumber daya dengan implementasi program SDIDTK, Menganalisis hubungan faktor disposisi dengan implementasi program SDIDTK, Menganalisis hubungan faktor struktur birokrasi dengan implementasi program SDIDTK, Menganalisis secara bersamasama faktor-faktor yang berhubungan dengan implementasi program SDIDTK

\section{METODE PENELITIAN:}

Jenis penelitian adalah penelitian observasional dengan pendekatan cross sectional study. Populasi dalam penelitian ini adalah seluruh bidan desa 


\section{$\begin{array}{llllll}\text { JURNAL KEBIDANAN } & \text { Vol. } 7 & \text { No.15 } & \text { April } 2018 & \text { ISSN.2089-7669 }\end{array}$}

yang berada di Wilayah Kabupaten Semarang sebanyak 229 orang. Sampel adalah bidan desa yang berada di wilayah puskesmas yang cakupan SDIDTKnya rendah yaitu 62 bidan Desa yang terdiri dari 15 bidan desa dari Puskesmas Bergas, 9 bidan Desa dari Puskesmas Ungaran, 12 bidan desa dari Puskesmas Bawen, 17 Bidan desa dari Puskesmas Ambarawa, serta 9 bidan desa dari Puskesmas Leyangan. Teknik sampling adalah Purposive Sampling. Metode pengumpulan data dengan kuesioner tentang Komunikasi, sumber daya, disposisi dan Struktur birokrasi yang berkaitan dengan SDIDTK. Serta Implementasi (cakupan SDIDTK)

Hasil dan Pembahasan

\section{Hasil Univariat}

Diskripsi faktor Komunikasi, Sumber Daya, Disposisi, dan Struktur Birokrasi dalam implementasi Program SDIDTK

Tabel 4.1

Diskripsi faktor komunikasi, Sumber Daya, Disposisi, dan Struktur Birokrasi dalam implementasi Program SDIDTK

\begin{tabular}{|c|c|c|c|}
\hline & Kategori & $\begin{array}{c}\text { Frekue } \\
\text { nsi }\end{array}$ & $\begin{array}{c}\text { Prosent } \\
\text { ase }\end{array}$ \\
\hline \multirow[t]{2}{*}{ Komunikasi } & Baik & 31 & 50 \\
\hline & Kurang & 31 & 50 \\
\hline \multirow{2}{*}{$\begin{array}{l}\text { a. Transmi } \\
\text { si }\end{array}$} & Baik & 30 & 48,4 \\
\hline & Kurang & 32 & 51,6 \\
\hline \multirow[t]{2}{*}{ b. Clarity } & Baik & 35 & 56,5 \\
\hline & Kurang & 27 & 43,5 \\
\hline \multirow{2}{*}{$\begin{array}{l}\text { c. Konsiste } \\
\text { nsi }\end{array}$} & Baik & 38 & 61,3 \\
\hline & Kurang & 24 & 38,7 \\
\hline \multirow{3}{*}{$\begin{array}{l}\text { Sumber } \\
\text { Daya }\end{array}$} & Memadai & 38 & 61,3 \\
\hline & Kurang & & \\
\hline & Memadai & 24 & 38,7 \\
\hline \multirow[t]{3}{*}{ a. SDM } & Memadai & 44 & 71 \\
\hline & Kurang & & \\
\hline & Memadai & 18 & 29 \\
\hline $\begin{array}{l}\text { b. Anggara } \\
\mathrm{n}\end{array}$ & $\begin{array}{l}\text { Memadai } \\
\text { Kurang }\end{array}$ & 45 & 72,6 \\
\hline
\end{tabular}

\begin{tabular}{llcc}
\hline & Memadai & 17 & 27,4 \\
\hline c. Sarana & Memadai & 37 & 59,7 \\
\multicolumn{1}{c}{ Prasaran } & Kurang & & \\
& Memadai & 25 & 40,3 \\
\hline Disposisi & Baik & 39 & 62,9 \\
& Kurang & 33 & 37,1 \\
& Baik & & \\
\hline Struktur & Baik & 56 & 90,3 \\
Birokrasi & Kurang & 6 & 9,7 \\
& Baik & & \\
& & &
\end{tabular}

Tabel 4.1 menunjukkan bahwa dari 62 responden yang diberi kuesioner menyatakan komunikasi baik dan komunikasi kurang baik sama $50 \%$ dalam implementasi program SDIDTK. Jika dilihat dari sub variabel transimisi, clarity dan konsistensi didapatkan dari 62 responden 30 responden dengan kemampuan transmisi baik $(48,4 \%)$ dan transmisi kurang baik $(51,6 \%)$. Pada sub variabel clarity didapatkan dari 62 responden 35 responden dengan kemampuan clarity baik $(56,5 \%)$ dan clarity kurang baik $(43,5 \%)$. Sedangkan pada sub variabel konsistensi didapatkan dari 62 responden 38 responden dengan kemampuan konsistensi baik $(61,3 \%)$ dan konsistensi kurang baik $(38,7 \%)$

Variabel sumber daya menunjukkan dalam implementasi program SDIDTK sebagian besar atau $61 \%$ memadai dan $39 \%$ kurang memadai. Jika dilihat dari sub variabel sumber daya manusia, anggaran dan sarana prasarana didapatkan dari 62 responden 44 responden dengan SDM memadai $(71 \%)$ dan SDM kurang baik (29\%). Pada sub variabel anggaran didapatkan dari 62 responden 45 responden dengan anggaran memadai $(72,6 \%)$ dan anggaran kurang baik $(27,4 \%)$. Sedangkan pada sub variabel sarana prasarana didapatkan dari 62 responden 37 responden dengan sarana prasarana memadai $(59,7 \%)$ dan sarana prasarana kurang memadai $(40,3 \%)$. 
Variabel disposisi sebagian atau 62,9\% disposisi baikserta 37,1\% disposisi kurang baik. Variabel struktur Birokrasi mempunyai hasil 90,3\% struktur birokrasi dalam kategori baik.

\section{Hasil Bivariat}

Hubungan faktor komunikasi dengan implementasi program SDIDTK

Tabel 4.2

Hubungan Faktor komunikasi dengan implementasi program SDIDTK

\begin{tabular}{lllllll}
\hline & \multicolumn{4}{c}{ Implementasi } \\
\cline { 2 - 7 } $\begin{array}{l}\text { Komunik } \\
\text { asi }\end{array}$ & Sesuai & \multicolumn{2}{c}{$\begin{array}{c}\text { Tidak } \\
\text { Sesuai }\end{array}$} & Total \\
\hline & $\mathrm{N}$ & $\%$ & $\mathrm{~N}$ & $\%$ & $\mathrm{~N}$ & $\%$ \\
\hline Baik & 24 & 51,1 & 7 & 46,7 & 31 & 50 \\
Kurang & 23 & 48,9 & 8 & 53,3 & 31 & 50 \\
Baik & & & & & & \\
\hline Total & 47 & 100 & 15 & 100 & 62 \\
\hline $\mathrm{X}^{2}=0.000$ & $\mathrm{p}=1.000$ & & & & &
\end{tabular}

Tabel 4.2 menunjukkan bahwa dari program SDIDTK yang implementasinya sesuai cenderung komunikasinya baik sebesar 51,1\%. Lebih tinggi daripada yang komunikasinya kurang baik $(48,9 \%)$. Hasil penelitian menunjukkan nilai $\mathrm{p}$ value $=1,000$ sehingga tidak ada hubungan antara komunikasi dengan implementasi program SDIDTK. Hal ini tidak sesuai dengan Widodo,2011 yang menyatakan bahwa salah satu faktor yang mempengaruhi implementasi kebijakan adalah komunikasi, karena komunikasi merupakan Proses penyampaian informasi dari pembuat kebijakan (policy makers) kepada pelaksana kebijakan (policy implementors. Hasil dari analisa univariat menunjukkan bahwa metode sosialisasi yang diberikan kepada bidan desa adalah melalui ceramah, sehingga dengan menggunakan metode tersebut kurang efektif dalam penyampaian pesan kepada pelaksana kebijakan. Selain hal tersebut materi sosialisasi yang diberikan mengenai target minimal yang harus dicapai dalam program SDIDTK ini juga belum tersosialisasi dengan baik hal ini bisa menurunkan berjalannya program.

Hubungan faktor sumber daya dengan implementasi program SDIDTK

Tabel 4.3

Tabel silang Sumber daya dengan implementasi program SDIDTK

\begin{tabular}{|c|c|c|c|c|c|c|}
\hline \multirow{3}{*}{$\begin{array}{l}\text { Sumber } \\
\text { Daya }\end{array}$} & \multicolumn{6}{|c|}{ Implementasi } \\
\hline & \multicolumn{2}{|c|}{ Sesuai } & \multicolumn{2}{|c|}{$\begin{array}{l}\text { Tidak } \\
\text { Sesuai }\end{array}$} & \multicolumn{2}{|c|}{ Total } \\
\hline & $\mathrm{N}$ & $\%$ & $\mathrm{~N}$ & $\%$ & $\mathrm{~N}$ & $\%$ \\
\hline Memadai & $\begin{array}{l}3 \\
3\end{array}$ & $\begin{array}{l}70, \\
2\end{array}$ & 5 & $\begin{array}{l}33, \\
3\end{array}$ & $\begin{array}{l}3 \\
8\end{array}$ & 61,3 \\
\hline Kurang & 1 & 29 , & 1 & 66 , & 2 & 38,7 \\
\hline Memadai & 4 & 8 & 0 & 7 & 4 & \\
\hline Total & 4 & 10 & 1 & 10 & 6 & 100 \\
\hline & 7 & 0 & 5 & 0 & 2 & \\
\hline
\end{tabular}

Tabel 4.3 menunjukkan bahwa dari program SDIDTK yang implementasinya sesuai cendrung sumber dayanya lebih tinggi 70,2\% dibanding yang implementasinya tidak sesuai yaitu sebesar $33.3 \%$.

Berdasarkan hasil penelitian didapatkan bahwa ada hubungan antara faktor sumberdaya dengan implementasi program SDIDTK oleh bidan desa dengan $p$ value 0,025 . Sumber daya mempunyai peranan penting dalam implementasi kebijakan karena 
bagaimanapun

jelas

dan

konsisitensinya ketentuan-ketentuan dan aturan-aturan serta bagaimanapun akurantnya penyampaian ketentuan tersebut, jika pelakasana kebijakan yang bertanggung jawab untuk melaksanakan kebijakan kurang mempunyai sumber-sumber daya secara memadai maka implementasi kebijakan tersebut tidak efektif.

Hasil penelitian juga menunjukkan bahwa dari 62 responden mereka menyatakan bahwa jumlah bidan 74.2 $\%$ tercukupi dalam pelaksanaan SDIDTK. Sumber daya manusia (Human Resurce) merupakan sumber daya yang paling penting karena disamping sebagai subyek implementasi kebijakan juga merupakan objek kebijakan publik.

Dari hasil penelitian sumber daya metoda (method resources) atau sarana prasarana sebagian besar tersedia mulai dari alat pengukur berat badan dan tinggi badan, formulir KPSP, TDL, TDD, tersedia dan layak digunakan namun alat bantu pemeriksaan KPSP seperti alat -alat permainan 19,4\% menyatakan tidak ada, sehingga Dinas kesehatan perlu menyediakan sarana dan prasarana alat bantu pemeriksaan dalam pelaksanan SDIDTK. Menurut Gibson mengatakan ketersedian sarana dan prasarana berpengaruh terhadap implementasi kebijakan yang dalam hal ini adalah implementasi program SDIDTK. Hal ini juga sesuai dengan teori George C Edwards III yang menyatakan bahwa implementasi kebijakan harus ditunjang dengan sumber daya baik sumber daya manusia, materi dan metoda, jika kekurangan sumber daya tersebut, maka implementasi tidak akan berjalan efektif dan efisien. Tanpa sumber daya , kebijakan hanya tinggal dikertas menjadi dokumen saja tidak diwujudkan.

Hubungan faktor Disposisi dengan implemetasi program SIDTK

\section{Tabel 4.4}

Tabel silang Disposisi dengan implementasi program SDIDTK

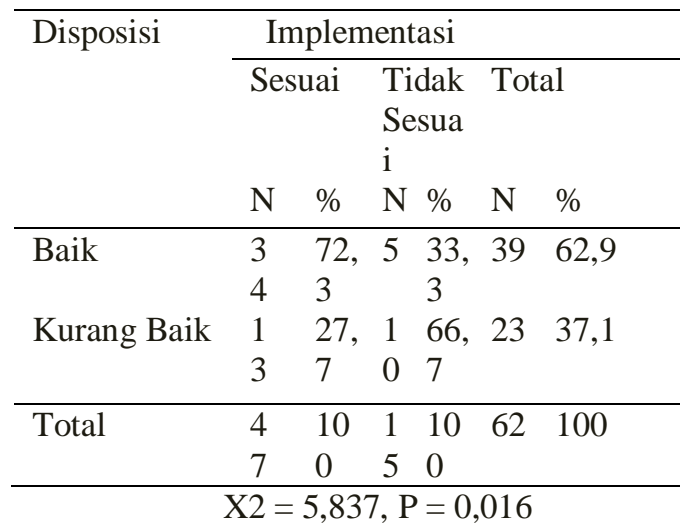

Tabel 4.4 menunjukkan bahwa Program SDIDTK yang implementasinya sesuai cenderung faktor disposisi baik lebih tinggi sebesar $72,3 \%$ dibanding yang kurang baik. Hasil penelitian didapatkan nilai $\mathrm{p}$ sebesar 0.016 sehingga hubungan yang bermakna antara faktor disposisi dengan implementasi program SDIDTK. Disposisi dalam implementasi merupakan suatu komitmen, sikap yang dimiliki oleh implementor kebijakan seperti komitmen, kejujuran, komunikatif, cerdik dan sifat demokratis. Hasil penelitian didapatkan bahwa dari 62 responden 72,9\% mempunyai disposisi baik, sehingga hal ini merupakan modal awal untuk berjalannya suatu program SDIDTK di Kabupaten Semarang, kecakapan saja tidak mencukupi tanpa kesediaan, komitmen dan sikap yang mendukung dari Implementor kebijakan. Sesuai dengan penelitian Setyadi Iwan 2005 mengenai Evaluasi implementasi proyek inovasi managemen perkotaan di Yog- 
yakarta menyatakan bahwa kunci keberhasilan program atau implementasi kebijakan adalah sikap para pekerja terhadap penerimaan dan dukungan atas kebijakan atau dukungan yang telah ditetapkan.

Hubungan faktor Struktur birokrasi dengan implementasi program SDIDTK

Tabel 4.5

Tabel silang struktur Birokrasi dengan implementasi program SDIDTK

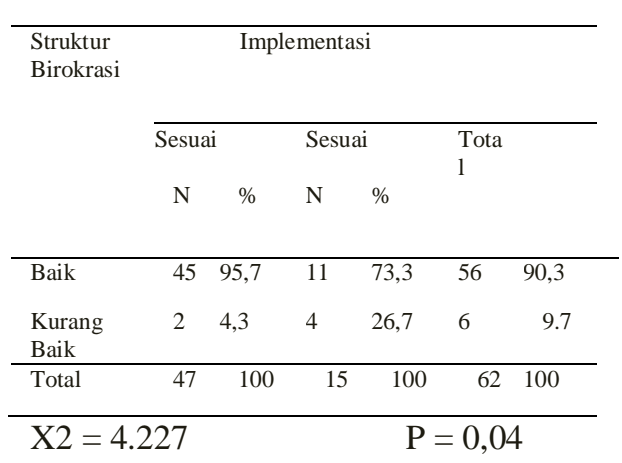

Tabel 4.5 menunjukkan bahwa program SDIDTK yang implementasinya sesuai cenderung struktur birokrasi baik sebesar 95,7\% lebih tinggi dibanding yang implementasi ya tidak sesuai yaitu sebesar $73,2 \%$. Hasil uji Chi Square didapatkan nilai $\mathrm{P}$ value sebesar $0.04(<\alpha 0.05)$ sehingga Ho ditolak dan Ha diterima, hal ini dapat disimpulkan bahwa ada hubungan yang bermakna antara faktor struktur Birokrasi dengan implementasi program SDIDTK.

Pengaruh Sumber daya, Disposisi, Struktur Birokrasi terhadap Implimentasi program SDIDTK

Tabel 4.7
Hasil Analisis Regersi Logistik Bivariat Sumberdaya dengan implementasi program SDIDTK

\begin{tabular}{|c|c|c|c|c|c|c|}
\hline Variabel & B & S.E & $\begin{array}{l}\text { Wal } \\
\text { d }\end{array}$ & $\begin{array}{l}\text { D } \\
\text { f }\end{array}$ & sig & $\begin{array}{l}\text { EXP } \\
\text { (B) }\end{array}$ \\
\hline $\begin{array}{l}\text { Sumber } \\
\text { daya }\end{array}$ & $\begin{array}{l}1.5 \\
51\end{array}$ & $\begin{array}{l}0.63 \\
4\end{array}$ & $\begin{array}{l}5.9 \\
85\end{array}$ & 1 & $\begin{array}{l}0.0 \\
14\end{array}$ & 4.714 \\
\hline Disposisi & $\begin{array}{l}1.6 \\
55\end{array}$ & $\begin{array}{l}0.63 \\
7\end{array}$ & $\begin{array}{l}6.7 \\
37\end{array}$ & 1 & $\begin{array}{l}0.0 \\
09\end{array}$ & 5.231 \\
\hline $\begin{array}{l}\text { Struktur } \\
\text { birokrasi }\end{array}$ & $\begin{array}{l}2.1 \\
2\end{array}$ & $\begin{array}{l}0.9 \\
29\end{array}$ & $\begin{array}{l}5.1 \\
19\end{array}$ & 1 & $\begin{array}{l}0,0 \\
24\end{array}$ & $\begin{array}{l}8.18 \\
2\end{array}$ \\
\hline
\end{tabular}

\begin{tabular}{|c|c|c|c|c|c|c|}
\hline & Varia & & S.E & & $\mathrm{Si}$ & \\
\hline & & $\mathrm{B}$ &. & Wald df & g. & $\operatorname{Exp}(B)$ \\
\hline \multirow[t]{4}{*}{$\begin{array}{l}\text { Step } \\
1^{\text {a }}\end{array}$} & $\begin{array}{l}\text { Disp } \\
\text { osisi }\end{array}$ & $\begin{array}{l}1.7 \\
88\end{array}$ & $\begin{array}{r}.72 \\
7\end{array}$ & $6.045 \quad 1$ & $\begin{array}{r}.0 \\
14\end{array}$ & 75 \\
\hline & $\begin{array}{l}\text { Struk } \\
\text { tur } \\
\text { Birok } \\
\text { rasi }\end{array}$ & $\begin{array}{r}1.1 \\
92\end{array}$ & $\begin{array}{r}1.0 \\
29\end{array}$ & $1.341 \quad 1$ & $\begin{array}{r}.2 \\
47\end{array}$ & 3.294 \\
\hline & $\begin{array}{l}\text { Sum } \\
\text { ber } \\
\text { Daya }\end{array}$ & $\begin{array}{r}1.6 \\
02\end{array}$ & $\begin{array}{r}.74 \\
1\end{array}$ & $4.672 \quad 1$ & $\begin{array}{r}.0 \\
31\end{array}$ & 4.964 \\
\hline & $\begin{array}{l}\text { Cons } \\
\text { tant }\end{array}$ & $\begin{array}{r}- \\
7.4 \\
79\end{array}$ & $\begin{array}{r}2.0 \\
05\end{array}$ & $\begin{array}{r}13.91 \\
4\end{array}$ & $\begin{array}{r}.0 \\
00\end{array}$ & .001 \\
\hline \multirow[t]{3}{*}{$\begin{array}{l}\text { Step } \\
2^{\mathrm{a}}\end{array}$} & $\begin{array}{l}\text { Disp } \\
\text { osis }\end{array}$ & $\begin{array}{r}1.9 \\
10\end{array}$ & $\begin{array}{r}.71 \\
4\end{array}$ & $7.159 \quad 1$ & $\begin{array}{r}.0 \\
07\end{array}$ & 6.751 \\
\hline & $\begin{array}{l}\text { Sum } \\
\text { ber } \\
\text { Daya }\end{array}$ & $\begin{array}{r}1.8 \\
16\end{array}$ & $\begin{array}{r}.71 \\
5\end{array}$ & 6.4601 & $\begin{array}{r}.0 \\
11\end{array}$ & 6.150 \\
\hline & $\begin{array}{l}\text { Cons } \\
\text { tant }\end{array}$ & $\begin{array}{r}- \\
6.6 \\
37\end{array}$ & $\begin{array}{r}1.8 \\
06\end{array}$ & $\begin{array}{r}13.50 \\
5\end{array}$ & $\begin{array}{r}.0 \\
00\end{array}$ & .001 \\
\hline
\end{tabular}

a. Variable(s) entered on step 1: kat_disp, Kat_Birokrasi, kat_sapras.

Tabel 4.11 menujukkan bahwa variabel yang paling dominan mempengaruhi implementasi program SDIDTK adalah : Disposisi dan Sumberdaya manusia. Disposisi yang baik akan meningkatkan implementasi program SDIDTK sebesar 6,751 lebih besar dibanding disposisi kurang baik, serta sumber daya yang mendukung 
akan meningkatkan implementasi program SDIDTK 6,150 lebih besar dibanding sumber daya yang tidak mendukung. Hal ini menunjukkan bahwa dengan komitmen dan dukungan sikap yang baik dari pelaksana program SDIDTK serta sumber daya yang mendukung maka implementasi program SDIDTK akan berjalan sesuai dengan harapan.

\section{SIMPULAN.}

Simpulan dalam penelitian ini adalah :

1. Diskripsi faktor-faktor yang berhubungan dengan implementasi program SDIDTK

a. Komunikasi baik maupun kurang baik sama $50 \%$

b. Sebagian besar sumber daya adalah baik yaitu sebesar $61,3 \%$

c. Sebagian besar factor disposisi adalah disposisi baik yaitu $62,9 \%$

d. Sebagian besar factor struktur birokrasi adalah baik yaitu sebesar 90,3\%

2. Tidak ada hubungan antara factor komunikasi dengan implementasi Program SDIDTK oleh bidan desa di wilayah Dinas Kesehatan Kabupaten Semarang

3. Ada hubungan antara factor sumberdaya, disposisi dan struktur birokrasi dengan implementasi Program SDIDTK oleh bidan desa di wilayah Dinas Kesehatan Kabupaten Semarang

4. Ada pengaruh secara bersama-sama antara disposisi dengan sumber daya dengan implementasi program SDIDTK, dan faktor yang paling dominan adalah factor disposisi.

\section{SARAN.}

Berdasarkan hasil analisis data yang menunjukkan adanya hubungan antara faktor sumber daya, disposisi, dan struktur birokrasi maka saran yang diberikan adalah:

1. Bagi Tenaga Kesehatan /Bidan Desa

Diharapkan Bidan desa mempunyai komitmen, tanggung jawab dan sikap yang kuat dalam implementasi program SDIDTK dengan cara meningkatkan pengetahuan dan ketrampilan dan berusaha mencintai pekerjaannya sebagai bidan desa.

2. Bagi Puskesmas

Puskesmas diharapkan memantau secara rutin sumberdaya materi yaitu alat pendukung untuk pemeriksaan SDIDTK dan sumber daya metoda /SOP. Serta memfasilitasi program pelatihan SDIDTK sehingga dapat meningkatkan pemahaman dan ketrampilan bidan desa.

3. Bagi Dinas Kesehatan

Kepada Dinas Kesehatan Kab. Semarang untuk memperhatikan dan memenuhi usulan dari bawah dalam rangka meningkatkan implementasi program SDIDTK Di Wilayahnya.

\section{DAFTAR PUSTAKA}

Depkes, R.I., Pedoman Pelaksanaan Stimulasi, Deteksi dan Intervensi Dini Tumbuh Kembang Anak di Tingkat Pelayanan Kesehatan Dasar, Jakarta, 2005.

Kementrian Kesehatan RI., Pedoman Pelaksanaan SDIDTK di Tingkat pelayanan kesehatan dasar, Jakarta 20012. 
Saidah,E.S ., Pentingnya Stimulasi Mental Dini. Jurnal Ilmiah Pendidikan Anak Usia Dini, Jakarta, 2003

DinkesKab. Semarang. Profil Kesehatan Kabupaten Semarang. Semarang,2009

Agusman.S., Deteksi dan Intervensi Dini Penyimpangan Tumbuh Kembang Akibat Defisiensi Zat Gizi Dalam Deteksi dan Intervensi Dini Penyimpangan Tumbuh Kembang Anak Dalam Upaya Optimalisasi Kualitas Sumber Daya Manusia., Balai Penerbit FK UI,Jakarta,1999

Semarang, D.K.K., Rencana Strategi Dinas Kesehatan Kabupaten Semarang Tahun ,Semarang, 2009

IBI, P., KEPMENKES RI nomor 369/MENKES/SK/III/2007. Jakarta,2007

Prawirosentono. S, Kebijakan kinerja Karyawan,Yogyakarta, 1999
Gibsons, James L, John M. Ivancevich, James H. Donelly, Organisasi, Perilaku struktur dan proses, jilid II , Bina Rupa Aksara, Tangerang, 2000.

Sudharmanto, KinerjaPengembangan Dan Kompetensi SDM, Pustaka Pelajar, Jakarta, 2009.

Simanora, Henry, Manajemen SDM, edisi 3, STIE YKPN, Yogjakarta, 2003

Soeprihanto, J. Penilaian Kinerja dan Pengembangan Karyawan, BPFE, Yogyakarta. 2000

Depkes, R.I., Pedoman Pelaksanaan Stimulasi, Deteksi dan Intervensi Dini Tumbuh Kembang Anak di Tingkat Pelayanan Kesehatan Dasar. Jakarta, 2010

Notoatmojo, Metodologi Penelitian Kesehatan Edisi Revisi, Rineka Cipta Jakarta 2002

Sugiyono, Statistika Untuk Penelitian, Alfabeta, Bandung, 2007.

Arikunto, Prodsedur Penelitian. Rineka Cipta,Jakarta, 1997. 